Copyright (C) 2021 by Cherkas Global University

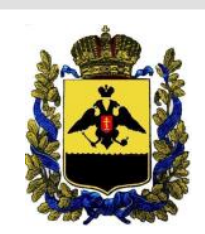

Published in the USA

Bylye Gody

Has been issued since 2006.

E-ISSN: 2310-0028

2021. 16(4): 1955-1963

DOI: $10.13187 /$ bg.2021.4.1955

Journal homepage:

https://bg.cherkasgu.press

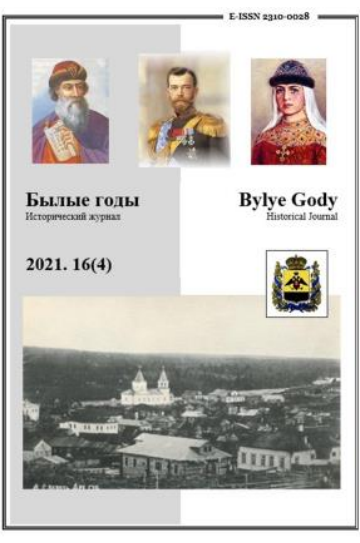

\title{
The Peoples of the Russian Empire's North in the Regional Press of the late XIX century
}

\author{
Daria S. Pchelkina a , ${ }^{*}$ Ksenia A. Degtyarenko a \\ a Siberian Federal University, Russian Federation
}

\begin{abstract}
The article aims to determine and analyze the regional image of the northern peoples of the Russian Empire at the end of the XIX century. The research materials are articles of the newspaper "Eastern Review", which was considered one of the leading local print publications of its time. The main attention of the authors is focused on the publications of the ethnocultural topics of the newspaper, in particular, dedicated to the indigenous peoples of the North of the Russian Empire.

The actual material of the study allows us to identify several main elements of the regional image of the peoples who inhabited the territory of Siberia at the end of the last century. These results were achieved during the qualitative content analysis of publications published in the "Eastern Review" issues in 1897.

The authors consider the specifics of the functioning of the periodical press as a historical document of the epoch and its role in creating a regional identity. Unlike generally recognized documents, which are traditionally considered as historical sources - legislative and political documents, scientific works, etc., periodicals record trends and moods that are relevant to society. At the end of the XIX century, the Eastern Review was considered the "voice of truth" for a large number of the population of the Asian part of Russia, representing the local everyday life. The periodical press has always actively participated and is taking part in filling in the gaps in the regional history of culture, in this case, related to the life of the indigenous smallnumbered peoples of the North of the Russian Empire at the turn of the XIX-XX centuries. Articles, notes and mentions of the northern peoples allow us to analyze not only the events recorded on the pages of the newspaper, but also the context in which they occur, the attitude of the authors of the newspaper publication and readers, which significantly reveals the regional image of the indigenous inhabitants of the territory of Siberia during this period.
\end{abstract}

Keywords: peoples of the North, the Russian Empire, regional identity, regional press, N.M. Yadrintsev.

\section{1. Введение}

Полевые исследования, посвященные этнокультуре коренных малочисленных народов Севера, стали проводиться на регулярной основе с первой трети XX века, в связи с чем наблюдается недостаток исторической информации о предшествующих периодах. Помимо нехватки исторических сведений, остро стоит вопрос достоверности уже имеющихся источников. В рамках данной темы исследования важнейшими информационными ресурсами становятся издания периодической печати Российской империи, в частности региональная пресса.

Региональная пресса представляет интерес как один из важнейших видов исторических источников, позволяющих сформировать образ, отношение к представителям различных этнокультурных групп и происходящим событиям. Официальные источники затрагивают формальные стороны общественных процессов, в том числе нормативно-правовые документы, высказывания официальных лиц. Подобного рода документы обращают внимание на актуальные

${ }^{*}$ Corresponding author

E-mail addresses: pchelkina.ml@mail.ru (D.S. Pchelkina), akseniya.krupkina@mail.ru (K.A. Degtyarenko) 
события и создают контекст происходящих событий, воссоздавая более целостную картину явлений. Газетные материалы дают широкие информативные возможности в изучении вопросов повседневности - они раскрывают жизнь обычных людей в определенный исторический период.

Материалы периодической печати, по мнению Б. Андерсона (Андерсон, 2016), являются инструментом конструирования национальной идентичности, так как люди, читая публикации на соответствующую тематику, становились сопричастными общей истории. Периодика позволяет погрузиться в контекст эпохи, атмосферу времени, что дает возможность исследователям подвергнуть анализу внутренние процессы, происходящие в социуме изучаемого периода. И в подобного рода публикациях высока роль субъективных факторов в формировании истории: отражены общее настроение жителей и автора статьи, заметки, чувства и отношения представителей разных слоев населения.

При этом важно понимать, что газеты являлись неотъемлемой частью общественного пространства как столичного, так и провинциального города. Периодика понималась как «зеркало» общества и как инструмент воздействия на людей, будучи доступным источником информации в разных сферах жизни. Содержание публикаций включало в себя раскрытие вопросов развития городов и региона в целом, образования и медицинского обслуживания, благоустройства, культуры и повседневности, т.е. посредством периодики велось региональное историческое бытописание. Период 1890-х годов для русской публицистики является знаменательным. Именно в это время происходит значительное развитие местной периодики. Как правило, каждая губерния обладала официальным печатным отделением. Главная роль в системе прессы конца XIX века принадлежит газетам, чье количество стремительно росло, многие из которых были ежедневными и еженедельными.

Целью данной статьи является определение исторического регионального образа коренных малочисленных народов Севера на основе анализа публикаций газеты «Восточное обозрение» за 1897 год как исторического источника.

\section{2. Материалы и методы}

2.1. В качестве материалов для исследования было выбрано региональное периодическое издание «Восточное обозрение» - еженедельная газета, учрежденная Николаем Ядринцевым в 1882 году. В ходе исследования был проведен общий анализ опубликованных в газете материалов за 1897 год. Для детального анализа отобраны следующие номера: 1-20, 34, 46, 48, 104-105, 109, $125-126,139,143,150,152$.

2.2. В качестве теоретического основания для исследования выбран подход, для которого характерно рассмотрение изданий периодической печати как исторических документов, наравне с источниками личного происхождения, делопроизводственными, законодательными, политикопублицистическими произведениями, научными трудами (Рынков, 2010).

В рамках данного исследования осуществлен качественный контент-анализ, выступающий одним из наиболее удобных инструментов выявления исторических процессов формирования региональной идентичности, изучения отношений внутри общества. Данный метод позволяет обратиться не только к темам публикаций, но и определить их цели и аудиторию.

Качественный контент-анализ не отрицает содержательного анализа документа, а дополняет его. Он позволяет обнаружить в материалах периодической печати не только фактологическую информацию, но и то, что имеет важный историко-социальный аспект, что может ускользнуть при обычном изучении текста. Тематический качественный контент-анализ статей региональной прессы позволяет определить контекст, сформированный спонтанно или целенаправленно, для чего использовались элементы интент-анализа.

Была применена техника сплошной выборки, в которой основным критерием отбора материала выступило упоминание в тексте о народах, проживающих на территориях Сибири и Дальнего Востока Российской империи в конце XIX века.

\section{3. Обсуждение}

Исторической динамике народов Севера посвящен ряд классических этнографических трудов (Дамешек, 1989; Долгих, 1970) и современных исследований (Кривоногов, 2017; Скобелев, 2013). «Этноатлас Красноярского края» освещает этногенез всех этнокультурных групп, проживающих на территории края с 1920-х годов. Помимо процесса этногенеза в целом, ученые уделяют внимание истории развития отдельных народов, в частности северных (Головнев, 1995; Копцева, 2018).

Исследователями отмечается высокая роль провинциальной прессы (Ланкина, 2016; Тушканов, 2015; Бочаров, Скобелев, 2013) для формирования социокультурного облика эпохи. Так, локальные средства массовой информации называются коллективным дневником, в котором «подробно фиксируется день за днем весь ход городской жизни» (Ланкина, 2016: 21), а зачастую и единственным сохранившимся документом, по которому возможно изучить и проанализировать контекст развития исторического периода в случае отсутствия источников другого вида (Тушканов, 2015: 78).

Газета «Восточное обозрение» занимала высокую позицию в ряду провинциальной прессы, а на территории Сибири и Дальнего Востока являлась одним из ведущих печатных изданий, по замечанию ряда исследователей (Гольдфарб, 1997; Гольдфарб, Бурдонов, 2011; Астафьев, 2011;

$$
-1956-
$$


Гончарова, Ягубов, 2019). Ученые отмечают, что для сибирского региона «Восточное обозрение» являлось основополагающим фактором общественной жизни, так как освещало ведущие политические, общественные, экономические и культурные явления. Авторский коллектив газеты представлял «оригинальную точку зрения на происходящие в России и мире процессы» (Гончарова, Ягубов, 2019: 87).

\section{4. Результаты}

\section{1. Общая характеристика источника}

Еженедельная газета «Восточное обозрение» была основана Николаем Ядринцевым в СанктПетербурге в 1882 году. Ее информационное наполнение носит региональный характер: оно отражает актуальные для своего времени исследования азиатской части Российской империи, актуальные известия в области политики, науки и образования, социальной и экономической сферах жизни в Сибири и на Дальнем Востоке.

На Рисунке 1 представлено оформление первого выпуска газеты «Восточное обозрение», вышедшего из печати 1 апреля 1882 года. На рисунке 2 представлен фрагмент обложки первого номера газеты за 1897 год, который позволяет отметить увеличившееся количество выпусков газеты за год: если в первый год своего существования она выходила один раз в неделю, то в 1897 году уже 3 раза в неделю (с 1894 года).

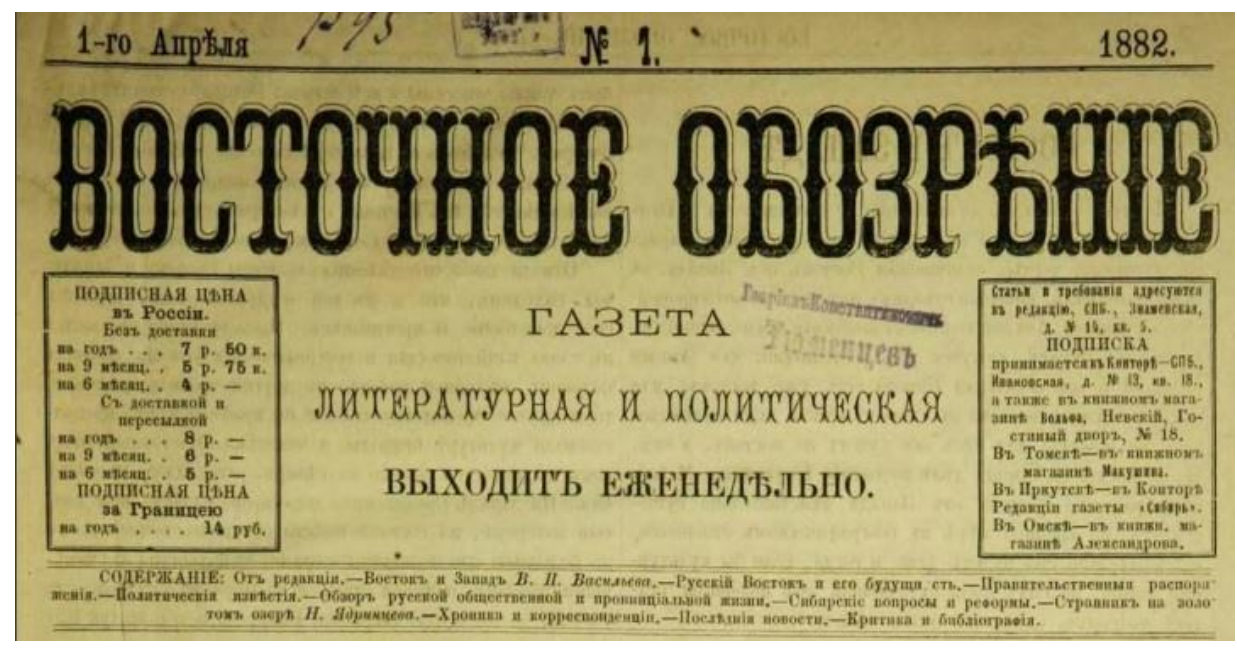

Рис. 1. Фрагмент обложки первого выпуска газеты «Восточное обозрение», 1882 год

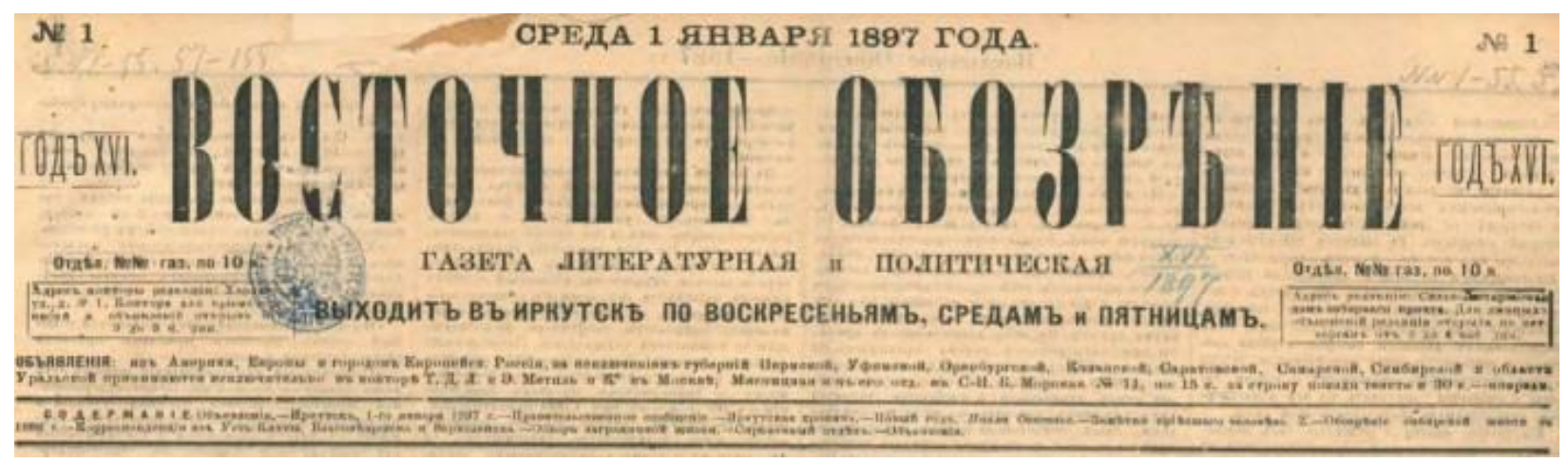

Рис. 2. Фрагмент обложки первого номера газеты «Восточное обозрение» за 1897 год

Основатель газеты Николай Михайлович Ядринцев - русский публицист, писатель, общественный деятель. Помимо издательской деятельности, он известен как выдающийся ученый: является первооткрывателем древнетюркских памятников в Монголии, а также автором большого количества монографий исторической, этнографической тематики. В 1888 году он перемещает издательство газеты в Иркутск, где ее развитие получает новый виток.

Именно в Сибири вокруг газеты сформировался круг местной и приезжей интеллигенции, политических ссыльных, многие из которых выступали одновременно в нескольких качествах публицистов, литераторов, общественных деятелей. Также нельзя не оценить вклад активистов газеты «Восточное обозрение» как исследователей Сибири, Центральной и Восточной Азии: 
немаловажной частью публикационного материала являлись сообщения и заметки о научных экспедициях и исследованиях сибирских ученых.

«Восточное обозрение» было не столько информационным источником, сколько толкователем «сибирского мирозерцания», «голосом правды» (Яковлев, Шишкин, 2003: 654), направляющим общественное мнение и играющим значимую роль в формировании региональной идентичности большой части читателей. К рубежу XIX-XX веков газета, по сути, заняла положение главного печатного издания Азиатской России, в котором собирались лучшие представители интеллектуальных сил того времени. Помимо Н.М. Ядринцева, среди авторов можно указать Г.Н. Потанина, С.С. Шашкова и многих других.

\section{2. Анализ содержания публикаций газеты «Восточное обозрение»}

Структура публикаций, разных заметок, статей носит характер гиперссылки: происходит обращение к предыдущим выпускам, в которых было упоминание какой-либо темы. Тем самым публикация носит не директивный характер, а читатель включается в течение повседневной жизни, описываемой на страницах газеты, формируется контекст.

Можно отметить яркий образный язык, обращение к читателям, использование юмористических оборотов, что создает эффект погружения в описываемые события.

Структура выпуска газеты включает в себя следующие пункты: объявления о купле-продаже, услугах и т.п. на первой и последней страницах; главные правительственные сообщения; информационные обзоры событий общественной и провинциальной жизни, хронику сибирских и восточных окраин Российской империи; происшествия; корреспонденцию из различных населенных пунктов азиатской части России; научное обозрение; литературное обозрение; обозрение русской жизни; обзор заграничной жизни; рекламный раздел. Основные этнокультурные группы Севера, которые упоминаются в выпусках газеты за 1897 год, - якуты, тунгусы, остяки, орочоны, юкагиры, чукчи, анадырцы.

Одним из элементов, который создает региональный образ северных народов, является род деятельности. Авторы публикаций отмечают, что представители коренных народов, с одной стороны, являются охотниками и добытчиками продовольственных товаров и пушнины, с другой - они в равной степени были связаны со сферой торговли, а именно - ярмарками, где происходил сбыт ресурсов. Коренное население понималось как основные поставщики мяса, птицы и пушнины: «Из Колымска пишут, что Анюйская ярмарка прошла «тихо»; чукчей было мало, много анадырцев... Промысел пушнины нынешней зимой был выше среднего. Даже в Верх. ок. местами добывали зайца. Так, на Дулгалахе (1-й Юсальский насл.) хороший промышленник добывал до 300 шт., плохой 100-150; во 2-м Байдунском насл. и на Тайбалахе - от 200 до 500 шт. Предложение пушнины на Анюе, благодаря удачному промыслу, было значительное. Куниц, бобров и соболей предлагали не дорого» («Восточное обозрение» № 105, 3 сентября 1897). Или: «В Якутске теперь специальная якутская ярмарка, и идет она крайне не бойко: якут обезденежел... Его продукты нынешнюю зиму не в цене: мясо в оптовой закупке 1 р. 80 к., масло 8 р. 50 к. И вот перед рекоставом на том берегу Лены скопилась масса якутов с пяти ближайших наслегов с своими продуктами: маслом, мясом, живым скотом» («Восточное обозрение» № 152, 21 декабря 1897).

При этом новостные сводки «Восточного обозрения» обнаруживают некоторые губительные факторы для традиционных видов хозяйственной деятельности народов Севера России и бытия самих народов в целом: «...вследствие хищнических приемов за последнее десятилетие сильно упал на Командорских островах котиковый промысел (с 551/2 т котиков на 17 т), доставлявший главнейшее средство пропитания туземцев, в числе 6оо человек» («Восточное обозрение» № 5, 10 января 1897); «летом 62 человека тунгусов отправились с оленями на Лену на рыбный промысел... На беду рыба, на которую они рассчитывали, ...не показывалась, и чтобы только не умереть с голоду, пришлось резать оленей. Но беда никогда одна не приходит: появляется зараза на оленей, сибирская язва или другая какая-нибудь, в точности не знаем. Важно то, что тунгусы ели павших оленей и, судя по слухам, из 52 человек в живых не осталось ни одного» («Восточное обозрение» № 5, 10 января 1897); «по поводу падежа оленей на Северо-Западе Сибири... скот пал, уловы зверя и рыбы плохие, народ питается плохим мясом болевших, исхудалых оленей..., положение аборигенов края печальное. Как бы ни были ограничены их потребности, как бы ни был привычен организм ко всякого рода лишениям и невзгодам, нужно опасаться, чтобы недостаточное питание, да еще мясом «болевших исхудалых оленей», не вызвало худшего бедствия - эпидемии, что очень легко может случиться. Население еще не успело оправиться после эпидемий тифа и черной оспы, свирепствовавшей 3-4 года назад, а если теперь появится что-нибудь вроде голодного тифа, можно с уверенностью сказать, что наших северных инородцев ждет фатальный конец» («Восточное обозрение» № 7, 15 января 1897).

Тематическое содержание показывает важную составляющую этнокультурной идентичности северных народов - регулярно упоминается связь с природой, подчеркивается зависимость качества бытовых и жизненных условий от погодных: «В 14 № «Восточного Обозрения» помещена статья с наставлением, что для якутян должны быть изменены предельные нормы понижения температуры, за которыми посещение школы прекращается. Министром Народного Просвещения уже сделано 
распоряжение, которым, на основании представлений директора Якутского реального училища, установлено, при скольких градусах мороза в г. Якутске необязательно для учащихся посещение местных учебных заведений» («Восточное обозрение» № 19, 12 февраля 1897). Городское население тем самым также отмечало подобные обстоятельства: «Весна была у нас маловодна, и, благодаря этому, плохо удались травы заливных мест, и даже водной дичью якут мало полакомится: мало воды - мало дичи, это общее правило. Лесная дичь, по малоснежию не могшая зарываться в снег на ночевки, массами погибала еще зимою. В этом разгадка случаев удивительной дешевизны дичи зимою: глухаря, напр., можно было купить коп. за 30» («Восточное обозрение» № 98, 17 августа 1897); «каждую зиму, вместе с холодами и в их результате обострением борьбы за существование местной бедноты, с правильностью закона природы повторяется дороговизна многих из необходимейших продуктов» («Восточное обозрение» № 104, 31 августа 1897). В этом аспекте жизнь пришлого и местного населения уравнивалась, так как была одинаково подвержена воздействиям природы. Описывается особенность местной культуры - с большим интересом повествуется о зимовье в баргузинской тайге: «Оглядевшись в своем временном помещении, мы нашли в углу опрокинутый большой котел с пробитым дном и с пробитым краем, который заменяет здесь печь..., где отбит край, кладутся дрова..., дым из него выходит вверх через пробитое дно, а где крыша сделана дыра... Это было первое, самое настоящее таежное зимовье!» («Восточное обозрение» № 19, 12 февраля 1897).

Отдельное внимание уделяется этнокультурным, этнопсихологическим особенностям жизни народов Севера, при этом зачастую в публикациях присутствуют слова, обращения на языке северных народов, что показывает заинтересованность в понимании жизненных условий и спецификации территорий, являющихся традиционными для проживания коренных народов: «Ыэллыр (отдарок) во всеобщем употреблении у якутов. Он переносит нас к тому времени, когда якутская родовая организация еще не знала мены. Самодовлеющие коллективно-хозяйственные единицы находили все потребное собственными силами. Но если являлась какая-либо нужда, то требуемый предмет не покупали, а несли обладателю его подарок, причем заявляли о своей нужде. Характерным отличием ыэллыра от мены служит то, что меняемые таким образом вещи не только не равноценны, хотя бы приблизительно, но отдарок всегда во много раз должен быть ценнее подарка. Этим и пользуются, причем в руках власть имущих обычай этот превращается в обременительное вымогательство. <...> «Что в мыслях держа, ты гостишь» (Тугу санагар тутангнгы ыэллыгын)? - спрашивает якут. «Убоина нужна». - «Хорошо, подумаем». Сделка окончена» («Восточное обозрение» № 150, 17 декабря 1897).

В разделе литературных обозрений публикуются сказания коренных народов, в частности якутов: «Огневая старуха» («Восточное обозрение» № 9, 19 января 1897; «Восточное обозрение» № 12, 26 января 1897 - окончание); «Счастье Матресь» («Восточное обозрение» № 12, 26 января 1897; «Восточное обозрение» № 13, 29 января 1897 - продолжение; «Восточное обозрение» № 15, 2 февраля 1897 - окончание).

Специфика же диеты коренного населения была довольно чуждой или неприемлемой для горожан: «Говорят: что русскому здорово, то немцу смерть. Доля правды в этом есть. Ни один немец не вынесет безнаказанно потребления мякинного хлеба, не говоря о специально «якутском», или серой капусты, не говоря о потреблении тех трав, которые ест якут даже не в голодное время...» («Восточное обозрение» № 104, 31 августа 1897). «Здесь всегда найдете рыбу с душком, и привычные якутские желудки отлично переваривают то, что другого уложило бы на месте» («Восточное обозрение» № 139, 21 ноября 1897).

При этом в публикациях этнокультурной направленности явно прослеживается необходимость сохранения уникальной культуры коренных народов северных территорий Российской империи: «В несравненно худшем положении, чем переселенцы, находятся сибирские инородцы, особенно живущие на севере Зап. Сибири. Ученые исследователи уже обратили внимание на вымирающие инородческие племена и указывают на необходимость прийти к ним на помощь и защитить их от эксплуатации промышленников» («Восточное обозрение» № 2, 3 января 1897); касательно возобновления деятельности этнографической секции Иркутского отдела РГО - «первобытные черты и особенности инородч жизни сглаживаются, теряются с каждым днем и наносятся наслоениями пришлой культуры, что стало быть, в его прямую обязанность должны входить заботы о том, чтобы возможно скорее и возможно полнее в то же время зарегистрировать эти убывающие и исчезающие черты» («Восточное обозрение» № 14, 31 января 1897); «якут как огня боится русской колонизации. При мало-мальски серьезных размерах ее местной администрации предстоит серьезная задача: обмежевание и ограждение интересов якута» («Восточное обозрение» № 146, 7 декабря 1897). Отдельным блоком идут информационные сообщения или полноценные очерки, посвященные культурно-просветительской и образовательной деятельности на сибирских и восточных территориях Российской империи, в том числе среди инородческого населения. Так, в первом номере газеты «Восточное обозрение» за 1897 год в начальном разделе статьи «Обозрение сибирской жизни за 1896 г.», посвященном народному образованию, сообщается следующее: «Потребность в высшем образовании с каждым годом увеличивается в Сибири. К нему начали приобщаться такие далекие окраины, как Якутск и Владивосток. В последнем городе мещанское общество дает даже пособие для получения высшего образования. Якуты по своей бедности такого пособия не в состоянии дать, 
но сама молодежь, ищущие высшего образования, обладает достаточною энергией, чтобы пробить себе дорогу. Нам передавали, что один якут, будучи томским студентом, летом для приобретения необходимых ему денежных средств, нанимался на сельские работы к окрестным крестьянам» («Восточное обозрение» № 1, 1 января 1897). Этнографическая тема является одной из ведущих в разделе научного обозрения газеты. Так, в четвертом номере за 1897 год размещена рецензия на антропологический очерк Н.Л. Геккера «К характеристике физического типа якутов», опубликованного в Записках Восточно-Сибирского отделения Русского географического общества по этнографии за 1896 год (т. 3, вып. 1). В том числе автор рецензии публикует основные выводы Н.Л. Геккера с собственными комментариями («Восточное обозрение» № 4, 8 января 1897).

Десятый номер за 1897 год знакомит читателей с результатами экспедиции Вилькицкого, целью которой было исследование устьев Енисея и Оби, где есть упоминание и о северных народах: «На всем 10о0-верстном протяжении Обской губы экспедиция не встретила ни одной живой души... Насколько на судах экспедиции велика была радость увидеть, наконец, берега, заселенные человеком, настолько появлением судов были напуганы дикари. Остяки подошли к судам и когда увидели па палубе одного из пароходов проводника, взятого экспедицией с ближайшего рыболовного станка, то поспешно и с беспокойством его спросили: «Чьи это люди, нашего ли они царя?» И только когда рыболов их совершенно успокоил на этот счет, остяки принесли членам экспедиции хлеба и рыбы» («Восточное обозрение» № 10, 22 января 1897). В одиннадцатом номере за 1897 год опубликована рецензия на «Рассказы о Восточной Сибири, т.е. о губерниях Енисейской и Иркутской, об области Приморской и об округах Якутском и Забайкальском», составленные Ф. Девелем («Восточное обозрение» № 11, 24 января 1897). В двадцатом номере за 1897 год дается обзор основных докладов заседания этнографической секции Восточно-Сибирского отдела Императорского Русского географического общества от 6 февраля 1897 года, в том числе о результатах амурской экспедиции Р.К. Маака и якутской экспедиции И.М. Сибирякова, и этом же номере опубликована рецензия на работу В.В. Бартенева «Понятия обдорских остяков о грехе» («Восточное обозрение» № 20, 14 февраля 1897).

\section{5. Заключение}

Результаты анализа публикаций еженедельной газеты «Восточное обозрение» позволяют сформировать представление о региональном образе северных народов в конце XIX века, об особенностях взаимоотношений между представителями коренных этнокультурных групп и пришлым населением, характер их отношений.

В ходе исследования были выделены элементы, составляющие образ коренных народов в конце XIX века, которые были определены в результате проведенного контент-анализа. Среди них можно выделить следующие: представители коренных народов Севера воспринимались жителями городов как часть повседневной жизни, связанной с торговой сферой: они являлись поставщиками и продавцами мяса, пушнины; подчеркнутая этнокультурная уникальность, особенность северных народов; также их образ наделялся особыми этнопсихологическими характеристиками выполняющими обещания, дорожащими культурой. Основные упоминания связаны с якутами, юкагирами, тунгусами, остяками и т.д., т.е. присутствовала спецификация групп коренных северных народов на уровне повседневной жизни.

Из анализа этих исторических источников следует, что, с одной стороны, в большинстве своем коренное население проживало в крайне тяжелых условиях, но, с другой - отмечается почти невероятная способность этих людей адаптироваться к суровым природным условиям, довольствуясь лишь самым необходимым. При том практически всеми авторами заметок, статей отмечается открытый к взаимодействию и дружелюбный характер.

Отдельно стоит отметить активную образовательную и просветительскую деятельность, развивающуюся на азиатских территориях Российской империи, а также особый интерес к изучению и сохранению этнокультурной специфики народов Севера.

\section{6. Благодарности}

Работа выполнена в рамках реализации проекта РФФИ № 21-о9-43014 «"Великое братство народов" (В.Н. Увачан): национальная политика СССР по отношению к коренным малочисленным народам Севера в Эвенкийском и Таймырском национальных (впоследствии - автономных) округах Красноярского края в 1920-1970-е гг.».

\section{Литература}

Андерсон, 2016 - Андерсон Б. Воображаемые сообщества. Москва, 2016. 416 с.

Астафьев, 2011 - Астафъев П.А. Газета «Восточное обозрение» как орудие общественного контроля в алтайских событиях 1882-1883 годов // Исторический ежегодник: Сборник статей. 2011. С. $45-55$.

Бочаров, Скобелев, 2013 - Бочаров А.В., Скобелев К.В. Опыт разработки методики контентанализа отражения крестьянской жизни в сибирской периодической печати начала ХX века 
(на примере газеты «Восточное обозрение» за январь 1905 г.) // Вестник Томского государственного университета. 2013. № 367. С. 58-63.

Головнев, 1995 - Головнев A.B. Говорящие культуры традиции самодийцев и угров. Екатеринбург, 1995. 216 c.

Гольдфарб, 1997 - Гольдфарб С.И. Газета «Восточное обозрение» (1882-1906). Иркутск, 1997.

Гольдфарб, Бурдонов, 2011 - Гольдфарб С.И., Бурдонов Н.В. «Восточное обозрение». Иркутск: 350-летию Иркутска посвящается. Иркутск, 2011. 594 с.

Гончарова, Ягубов, 2019 - Гончарова T.Н., Ягубов А.Х. Феномен западного колониализма на страницах газеты «Восточное обозрение» // Труды кафедры истории Нового и Новейшего времени. 2019. № 19-2. С. 87-104.

Дамешек, 1989 - Дамешек Л.М. Динамика и национальный состав коренного населения Сибири в период капитализма (1861-1917) // Исторический опыт социально-демографического развития Сибири. Вып. I: Палеодемография и демографические процессы в Сибири в эпоху Феодализма и капитализма. 1989. С. 98.

Долгих, 1970 - Долаих Б.О. Очерки по этнической истории ненцев и энцев. М., 1970.

Иванова, 2018 - Иванова Л.Д. Система газетной прессы на рубеже XIX-XX вв. // Известия Уральского федерального университета. Сер. 1 «Проблемы образования, науки и культуры». 2018. 24(2). С. 5-12.

Кискидосова, 2020 - Кискидосова T.A. «Городская повседневность» в региональной периодике второй половины XIX - начала XX века: обзор современной историографии // Гуманитарный вектор. 2020. № 15 (3). С. $73-81$.

Копцева и др., 2012 - Копцева Н.П., Амосов А.Е., Бахова Н.А., Бокова В.И., Булак К.А., Задорожная А.В., Заложнева М.С., Замараева Ю.С., Ильбейкина М.И., Кеуш А.И., Кивкуцан Г.В., Кирко В.И., Кистова А.В., Кривоногов В.П., Либакова Н.М., Лузан В.С., Махонина А.А., Медянцева Н.В., Ноздренко Е.А., Пименова Н.Н., Рафиков Р.Г., Резникова К.В., Савраменко Ю.А., Саймова В.С., Саушкина У.В., Семенова А.А., Синькевич Е.А., Сертакова Е.А., Федина Е.В., Шмидт Ю.В. Коренные малочисленные народы Севера и Сибири в условиях глобальных трансформаций (на материале Красноярского края). Красноярск, 2012. 639 с.

Кривоногов, 2017 - Кривоногов В.П. Этнические процессы у коренных малочисленных народов. Красноярск, 2017. 96 с.

Ланкина, 2016 - Ланкина Ю.С. Социокультурное развитие городов юга Приамурского генералгубернаторства в 1884-1913 гг.: Автореф. дис. ... канд. ист. наук: 07.00.02. 2016. 22 с.

Этноатлас Красноярского края, 2018 - Этноатлас Красноярского края, 2018. Гл. ред. Рафиков Р.Г. Красноярск, 2018. 224 с.

Рынков, 2010 - Рынков В.М. Периодическая печать: место в системе исторических источников // Отечественные архивы. 2010. № 3. С. 44-50.

Севостьянова, 2019 - Севостьянова E.B. «Дряхлый Восток заставил говорить о себе...»: Китай и Япония на страницах газеты «Восточное обозрение» в последней четверти XIX в. // Российскокитайские исследования. 2019. № 3 (3). С. 62-75.

Скобелев, 2013 - Скобелев С.Г. Демография коренного населения Сибири: объективистское направление в дореволюционной отечественной историографии (материалы для учебного курса) // Вестник Новосибирского государственного института. Серия «История, философия». 2013. № 12 (5). C. 6-11.

Тушканов, 2015 - Тушканов Д.И. Изучение периодической печати Царицына: историографический обзор // Актуальные проблемы истории - краеведческие исследования: Сборник научных работ. 2015. С. 78-83.

Фельштинский, Чернявский, 2012 - Фельитинский Ю., Чернявский Г. Усть-Кут и Верхоленск. «Восточное обозрение». М., 2012. 448 с.

Яковлев, Шишкин, 2003 - Яковлев А.Н., Шишкин В.И. Процесс над колчаковскими министрами. Май 1920. М., 2003. 672 с.

References

Anderson, 2016 - Anderson, B. (2016). Voobrazhaemye soobshchestva [Imaginary communities]. Moscow. [in Russian]

Astaf'ev, 2011 - Astaf'ev, P.A. (2011). The newspaper "Eastern Review" as an instrument of public control in the Altai events of 1882-1883. Istoricheskij ezhegodnik: sbornik statej. Pp. 45-55. [in Russian]

Bocharov, Skobelev, 2013 - Bocharov, A.V., Skobelev, K.V. (2013). Experience in developing a methodology for content analysis of the reflection of peasant life in the Siberian periodical press of the early XX century (on the example of the newspaper "Eastern Review" for January 1905). Vestnik Tomskogo gosudarstvennogo universiteta. 367: 58-63. [in Russian]

Dameshek, 1989 - Dameshek, L.M. (1989). Dynamics and ethnic composition of the indigenous population of Siberia during the period of capitalism (1861-1917). Istoricheskii opyt sotsial'no- 
demograficheskogo razvitiya Sibiri. Vyp. I: Paleodemografiya i demograficheskie protsessy $v$ Sibiri $v$ epokhu feodalizma i kapitalizma. P. 98. [in Russian]

Dolgikh, 1970 - Dolgikh, B.O. (1970). Ocherki po etnicheskoi istorii nentsev i entsev [Essays on the ethnic history of the Nenets and Enets]. M. [in Russian]

Etnoatlas Krasnoyarskogo kraya, 2018 - Etnoatlas Krasnoyarskogo kraya, 2018. Ed. by Rafikov R.G.

[Ethnoatlas of the Krasnoyarsk region]. Krasnoyarsk. [in Russian]

Fel'shtinskiy, Chernyavskiy, 2012 - Fel'shtinskiy, Yu., Chernyavskiy, G. (2012). Ust'-Kut and Verholensk. "Vostochnoe obozrenie" [Ust'-Kut and Verholensk. «Eastern Review»]. Moscow. [in Russian]

Gol'dfarb, 1997 - Gol'dfarb, S.I. (1997). Gazeta «Vostochnoe obozrenie» (1882-1906) [The newspaper

"Eastern Review" (1882-1906)]. Irkutsk. [in Russian]

Gol'dfarb, Burdonov, 2011 - Gol'dfarb, S.I., Burdonov, N.V. (2011). «Vostochnoe obozrenie». Irkutsk:

k 350-letiyu Irkutska posvyashchaetsya [«Eastern Review». Irkutsk: dedicated to the 350th anniversary of Irkutsk]. Irkutsk. [in Russian]

Golovnev, 1995 - Golovnev, A.V. (1995). Govoryashchie kul'tury traditsii samodiitsev i ugrov

[Speaking cultures and traditions of the Samoyeds and Ugrians]. Ekaterinburg. [in Russian]

Goncharova, Yagubov, 2019 - Goncharova, T.N., Yagubov, A.H. (2019). Fenomen zapadnogo

kolonializma na stranicah gazety «Vostochnoe obozrenie». Proceedings of the Department of History of Modern and Modern Times. 19-2: 87-104. [in Russian]

Goncharova, Yagubov, 2019 - Goncharova, T.N., Yagubov, A.H. (2019). The phenomenon of Western colonialism on the pages of the newspaper «Eastern Review». Trudy kafedry istorii Novogo i Novejshego vremeni. 19-2: 87-104. [in Russian]

Ivanova, 2018 - Ivanova, L.D. (2018). The system of the newspaper press at the turn of the XIXXX centuries. Izvestiya Ural'skogo federal'nogo universiteta. Ser. 1, Problemy obrazovaniya, nauki $i$ kul'tury. 24(2): 5-12. [in Russian]

Kiskidosova, 2020 - Kiskidosova, T.A. (2020). «Urban everyday life» in regional periodicals of the second half of the XIX-early XX century: a review of modern historiography. Gumanitarnyj vektor. 15(3): 73-81. [in Russian]

Koptseva i dr., 2012 - Koptseva, N.P., Amosov, A.E., Bahova, N.A., Bokova, V.I., Bulak, K.A., Zadorozhnaya, A.V., Zalozhneva, M.S., Zamaraeva, Yu.S., Il'bejkina, M.I., Keush, A.I., Kivkucan, G.V., Kirko, V.I., Kistova, A.V., Krivonogov, V.P., Libakova, N.M., Luzan, V.S., Mahonina, A.A., Medyanceva, N.V., Nozdrenko, E.A., Pimenova, N.N., Rafikov, R.G., Reznikova, K.V., Savramenko, Yu.A., Sajmova, V.S., Saushkina, U.V., Semenova, A.A., Sin'kevich, E.A., Sertakova, E.A., Fedina, E.V., Shmidt, Yu.V. (2012). Korennye malochislennye narody Severa i Sibiri v usloviyakh global'nykh transformatsii (na materiale Krasnoyarskogo kraya) [Indigenous small-numbered peoples of the North and Siberia in the context of global transformations (based on the material of the Krasnoyarsk region)]. Krasnoyarsk. [in Russian]

Krivonogov, 2017 - Krivonogov, V.P. (2017). Etnicheskie processy u korennyh malochislennyh narodov [Ethnic processes among indigenous small-numbered peoples.]. Krasnoyarsk, 2017. [in Russian]

Lankina, 2016 - Lankina, Yu.S. (2016). Sociokul'turnoe razvitie gorodov yuga Priamurskogo generalgubernatorstva v 1884-1913 gg. [Sociocultural development of cities in the South of the Amur General government in 1884-1913]. Irkutsk. [in Russian]

Rynkov, 2010 - Rynkov, V.M. (2010). Periodicals: a place in the system of historical sources. Otechestvennye arkhivy. 3: 44-50. [in Russian]

Sevost'yanova, 2019 - Sevost'yanova, E.V. (2019). "The decrepit East made us talk about ourselves...»: China and Japan on the pages of the newspaper "Eastern Review" in the last quarter of the XIX century. Rossijsko-kitajskie issledovaniya. 3(3): 62-75. [in Russian]

Skobelev, 2013 - Skobelev, S.G. (2013). Demography of the indigenous population of Siberia: the objectivist direction in pre-revolutionary Russian historiography (materials for the training course). Vestnik Novosibirskogo gosudarstvennogo instituta. Seriya: istoriya, filosofiya. 12(5): 6-11. [in Russian]

Tushkanov, 2015 - Tushkanov, D.I. (2015). Izuchenie periodicheskoj pechati Caricyna: istoriograficheskij obzor [Studying the Tsarityno periodical press: a historiographical review: collection of scientific works]. Aktual'nye problemy istorii - kraevedcheskie issledovaniya: sbornik nauchnyh rabot. Pp. 78-83. [in Russian]

Yakovlev, Shishkin, 2003 - Yakovlev, A.N., Shishkin, V.I. (2003). Process nad kolchakovskimi ministrami. Maj 1920. [The trial of the Kolchak ministers. May 1920]. Moscow. [in Russian] 


\section{Северные народы Российской империи в региональной прессе конца XIX века}

Дарья Сергеевна Пчелкина а, ${ }^{\text {, }}$ Ксения Александровна Дегтяренко ${ }^{\text {a }}$

a Сибирский федеральный университет, Российская Федерация

Аннотация. В статье поставлена задача определить и проанализировать региональный образ северных народов Российской империи конца XIX века. Материалами исследования выступают статьи газеты «Восточное обозрение», считавшейся одним из ведущих местных печатных изданий своего времени. Основное внимание авторов сосредоточено на публикациях этнокультурной тематики газеты, в частности посвященных коренным народам Севера Российской империи.

Фактический материал исследования позволяет выделить несколько основных элементов регионального образа народов, населявших территорию Сибири в конце позапрошлого столетия. Эти результаты были достигнуты в ходе проведения качественного контент-анализа публикаций, размещенных в выпусках «Восточного обозрения» в 1897 году.

Авторами рассмотрена специфика функционирования периодической печати как исторического документа эпохи и ее роль в создании региональной идентичности. В отличие от общепризнанных документов, которые традиционно рассматриваются в качестве исторических источников - законодательные и политические документы, научные труды и т.п., периодические издания фиксируют актуальные для общества тенденции, настроения. «Восточное обозрение» в конце XIX века считалась «голосом правды» для большого количества населения азиатской части России, представляя локальное бытописание. Периодическая печать всегда активно принимала и принимает участие в заполнении пробелов в региональной истории культуры, в данном случае связанных с жизнью коренных малочисленных народов Севера Российской империи на рубеже XIX$\mathrm{XX}$ веков. Статьи, заметки и упоминания северных народов позволяют проанализировать не только фиксируемые на страницах газеты события, но и контекст, в котором они происходят, отношения авторов публикации газеты и читателей, что содержательно раскрывает региональный образ коренных жителей территории Сибири в указанный период.

ключевые слова: коренные народы Севера, Российская империя, региональная идентичность, региональная пресса, Н.М. Ядринцев.

\footnotetext{
* Корреспондирующий автор

Адреса электронной почты: pchelkina.ml@mail.ru (Д.С. Пчелкина), akseniya.krupkina@mail.ru (К.A. Дегтяренко)
} 